\title{
A ironia na obra de Guimarães Rosa ou a capacidade encantatória de um divino embusteiro
}

Lélia Parreira Duarte | PUC Minas

Resumo: O ensaio procura demonstrar que Rosa é um embusteiro e contador de divinos poderes que, usando diferentes tipos de ironia, consegue fazer seu leitor desligar-se da realidade para penetrar no mundo encantado da ficção.

Palauras-chave: Guimarães Rosa, ironia, humor, fingimento, metaliteratura.

Conta um diálogo de Platão que o rapsodo Íon era capaz de recitar Homero como ninguém. E que Sócrates, com a sua maiêutica, lhe demonstra que ele não tinha na verdade uma arte, havendo duas hipóteses para o seu sucesso: ou ele atuava por efeito de inspiração divina, ou era um embusteiro. Guimarães Rosa parece ser uma nova encarnação de Íon, pois também ele tem essa capacidade de envolver e co-mover o seu auditório - de ouvintes, de leitores - ao transmitir-lhes narrativas de outros, que viriam de deuses ou seriam resultado de embustes, capazes de fazer os receptores saírem de sua realidade para um mundo de ficção. 
Em ambos os casos, se apresentaria como verdade o que está fora da jurisdição do comum dos mortais, ultrapassa o seu entendimento, de alguma forma e, por isso mesmo, não se submete às leis que governam os cidadãos comuns, pois tanto o que tem inspiração divina quanto o embusteiro caracterizam-se por usar palavras e metáforas que sabidamente constroem disfarces e representação. Como o ironista, não dizem eles o que dizem, pois tentam passar por verdade o que é do campo da ficção e não pode ser comprovado por meios normais, escapando, por isso, às determinações da sociedade: ou por pairar acima delas, por efeito de divinos poderes, ou por fugirem delas a partir do poder de enganar.

Tanto as estórias de Íon quanto as de G. Rosa, muitas vezes, dão a entender que não dizem o que dizem. Seus textos não seriam originais e sim reproduções de estórias já contadas ou reelaborações de enredos e sentidos, podendo ser vistos como traduções ou como exercícios de metalinguagem que contam o contar. De certa forma, é como se dissessem que nada do que for dito poderá resolver o problema do ser humano, porque não poderá libertá-lo de sua contingência, de sua relatividade, de sua condenação à morte. Mas, através das narrativas, tanto o contador de divinos poderes quanto o embusteiro e tanto Íon quanto Guimarães Rosa (assim como certamente outros bons contadores de estórias) podem, com refinada ironia, ilusória e momentaneamente libertar o homem de suas limitações e da certeza de seu destino final. Isso porque esses contadores são especialistas na arte de representar, de encenar, de fingir - de usar diferentes tipos de ironia. E também porque a sua palavra é encantatória, tem uma música que embriaga, liberando um poder sensibilizador que é capaz de abstrair o homem do cotidiano e colocá-lo num intervalo que não é o espaço da luta pela vida, embora não seja o da alienação. Que não é o da promessa, o da salvação ou o da glória. Por isso mesmo, a "Menina de lá" não pode permanecer: o seu mundo não é deste reino...

Tanto o rapsodo grego quanto Guimarães Rosa seriam, portanto, ironistas enganadores de divinos poderes, por sua capacidade de fazer os leitores flutuarem fora da realidade, com estórias que privilegiam, por exemplo, a questão do intervalo, como na "Terceira margem do rio", em que o pai fica no espaço móvel da canoa, entre as duas margens do real. Ou com relatos que ficam no intervalo entre vários enredos, como em "Pirlimpsiquice", ou num espaço entre vários sentidos, como no "Famigerado". E também por construir tantas vezes personagens em trânsito, ou loucos, crianças, deficientes e 
velhos já meio incapacitados que, por isso mesmo, parecem capazes de fazer mergulhar o ser humano mais fundo em sua problemática, para observar que as alegrias são fugazes e os desejos sempre insatisfeitos, marcados pela ameaça inexorável da morte. Morte que se faz presente desde a mais tenra idade e se manifesta em perdas geralmente desapercebidas pelos outros, como a do menino de "As margens da alegria", que a conhece através do desaparecimento da "ríspida grandeza tonitroante do peru" (ROSA, 1994: 390). A esta perda se segue a percepção da insensibilidade do semelhante, pela visão do peru substituto que, ferozmente, bica a sangrenta cabeça remanescente do antecessor. O leitor acompanha o sofrimento do menino que perde, "num lufo, num átimo", a eternidade ou a certeza, com o sentimento de que lhe roubaram as mais belas coisas, "ministrando-lhe um miligrama de morte", ao destruir aquela beleza que "Satisfazia os olhos, era de se tanger trombeta" (Rosa, 1994: 390). A estória mostra, entretanto, que essa dor pode atenuar-se com a substituição de significantes, e o menino se consola da perda do objeto de encantamento ao maravilhar-se logo em seguida com o vagalume, "lindo - tão pequenino, no ar, um instante só, alto, distante, indo-se." (Rosa 1994: 392). E é assim que pode ter, "outra vez em quando, a Alegria" - com maiúscula, o que parece, entretanto, ligar-se à sua sensibilidade anteriormente demonstrada para a beleza própria da palavra, porque, mesmo antes de conhecer o encanto do peru, ele se repetia "em íntimo, o nome de cada coisa. A poeira, alvissareira. (...) A arnica, em candelabros pálidos. A aparição angélica dos papagaios. As pitangas e o seu pingar". (Rosa, 1994: 390).

Nesse sentido, a ironia de Guimarães Rosa será certamente de um tipo especial: não será socrática - aquela que se apresenta como ignorância simulada, com o objetivo de fazer ressaltar a ignorância real daquele com quem se discute. Não será também a ironia retórica usada na sátira com o objetivo de moralização dos costumes, em que sinais equivalentes a cotoveladas e piscadelas indicam que se diz o contrário do que se diz. Trata-se de uma ironia que valoriza mais o trabalho com a linguagem em si ou com sua significância, sua potencialidade, com o caráter que o texto pode ter de fingimento, de representação, de máscara consciente e exibida. Trata-se de uma ironia que se identifica mais com o humor, que tem o mesmo princípio da ironia de não dizer o que diz, mas que privilegia principalmente, em sua construção, a brincadeira, o significante. 


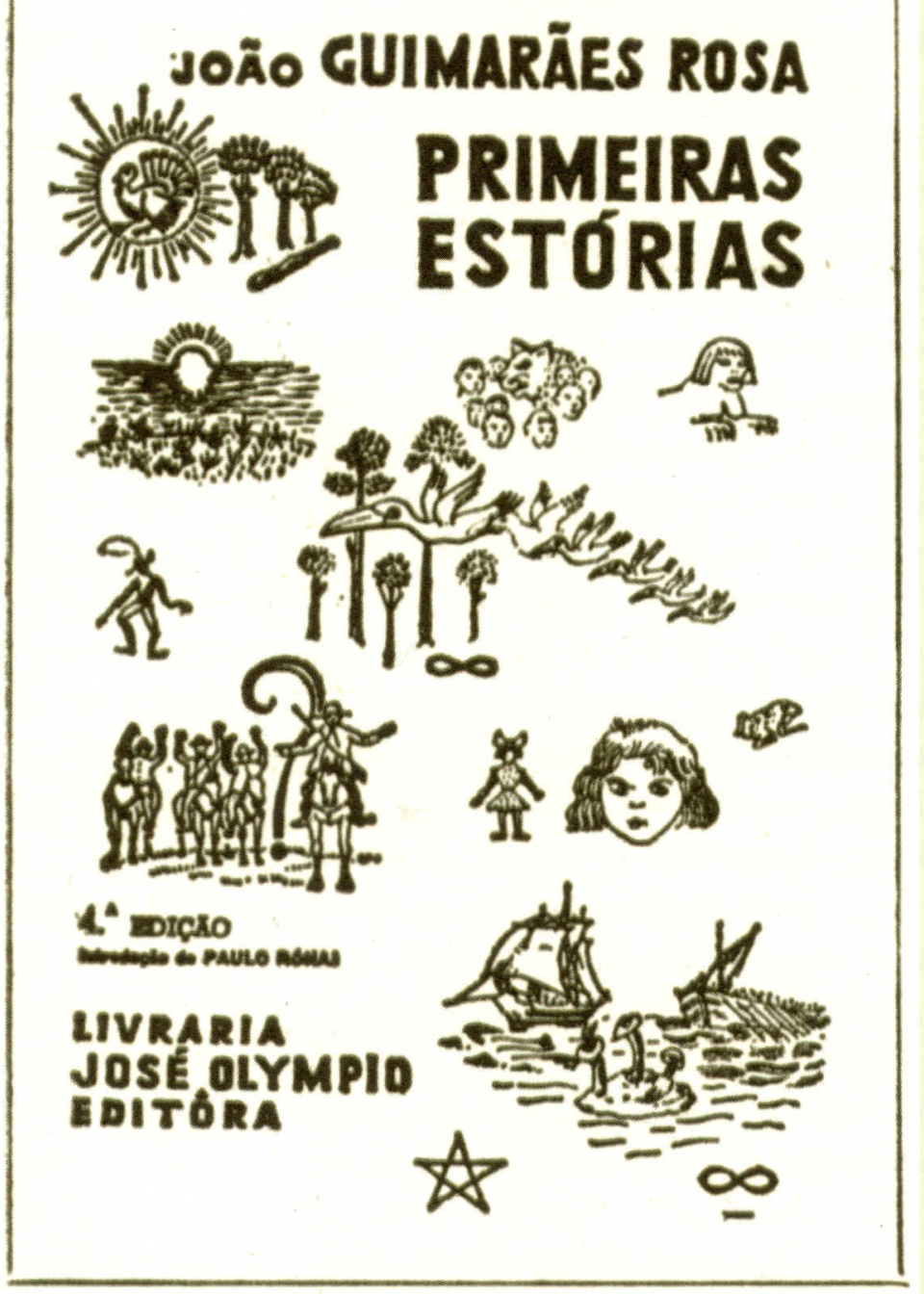


Muito mais que com o dito - a estória, a narrativa ou o seu significado -, preocupa-se o criador de Diadorim com o dizer, a elaboração desse dizer. Interessam-lhe mais que tudo os jogos de linguagem - o seu desamarramento dos sentidos estabelecidos, das certezas dos ditos -, mais a comunicação entre emissor e receptor que a mensagem, isto é, mais os pólos extremos ou o indecidível da comunicação (o tongue-in-cheek, de que fala Almansi (1978), que a mensagem comunicada. Mesmo porque as estórias mostram que as grandezas só se alcançam através das minúcias e nesse sentido talvez pudéssemos ver no título do Grande sertão: veredas uma piscadela irônica: trata-se do grande sertão indomável que só se pode conhecer relativa e parceladamente através das veredas - que só podem ser pequenas, na sua acepção dicionarizada de caminho estreito, senda, atalho. Rosa preferia mesmo falar de nonadas, tutaméias - ninharias, insignificâncias -, nadas com que gostava de brincar: "o nada é uma faca sem lâmina, da qual se tirou o cabo...". Ou "o nada é um balão, sem pele..." "Nada" presente na adivinha da menina do sertão, parecida com a Menina de lá: "O que é, o que é: é melhor do que Deus, pior do que o diabo, que a gente morta come, e se a gente viva comer morre?" Resposta: "É nada". (Rosa, 1994: 521).

Parece ser esse o motivo pelo qual Rosa valoriza tanto o trabalho de seus tradutores, a quem aconselhava que fossem criativos, explorando, como ele mesmo fazia em suas estórias, as potencialidades da linguagem. Pois os seus livros seriam "antiintelectuais", por defender "o altíssimo primado da intuição, da revelação, da inspiração, sobre o bruxolear presunçoso da inteligência reflexiva, da razão". (Rosa, 1980: 58).

Mas a ironia de Guimarães Rosa não se limita a esse tipo fluido, que Jankélévitch chama de ironia bumoresque. Embora não se apresente em sua obra uma ironia moralizadora, como a da sátira, que faz rir para castigar os costumes, com o objetivo de trazer os desviados a um bom caminho, prévia e ideologicamente traçado, suas estórias reproduzem, algumas vezes, os jogos de enganos da sociedade que, em sua luta pelo poder, usa a ironia antifrástica, aquela que diz o contrário do que parece dizer.

São freqüentes, em suas narrativas, personagens enganáveis por sua boa fé, fragilidade e ingenuidade. Outras, por fidelidade a seus preconceitos, como Riobaldo, não conseguem perceber sinais de que sua leitura está equivocada - de que Diadorim não é homem, como parece, e sim a mulher que ele poderia desejar, sem ofender as próprias conviç̧ões -, sendo, portanto, 
ironicamente ludibriadas por si mesmas. Há ainda as personagens poderosas e prepotentes, também sujeitas a serem enganadas por si mesmas ou por outras que, tranqüilas na crença em seus próprios poderes, podem ser iludidas por aquelas a quem dominavam ou enganavam. Um exemplo desse tipo estaria em "Esses Lopes", no qual os Lopes são enganados pela Flausina que subjugam e exploram, mas que depois os destrói, arriscando-se adiante a ser também enganada pelo homem amado e que talvez deseje apenas a fortuna que ela conseguiu amealhar. No caso desse conto, o leitor fica num equilíbrio difícil entre a empatia e o afastamento da personagem, que sofre a dominação dos poderosos Lopes e os vence a todos, devagar, com paciência e com sua aparente e fingida fragilidade. No entretanto, seus sonhos de amor podem também ser ironicamente irrealizáveis, pela sugerida possibilidade de desencontro irônico entre ela e seu amado, ficando assim inócuo o seu pacto com o diabo, que tinha por objetivo afinal uma felicidade que a personagem se arrisca a não alcançar.

Além desse jogo intradiegético, Rosa usa outra ironia para brincar com seu leitor. Cria às vezes um narrador que engana esse leitor, fazendo-o supor e esperar grandes desgraças, como acontece em "Os irmãos Dagobé", de Primeiras estórias, em que o narrador espalha o medo com seu relato, falando de "Enorme desgraça", de morte e de velório, dos irmãos "absolutamente facínoras", do receio dos presentes que preferiam ficar perto do defunto, no quarto pequeno daquela casa grande, porque "temiam mais ou menos os três vivos" (Rosa, 1994: 405). Esse narrador mostra os Dagobés como "demos, gente que não prestava" (Rosa, 1994: 404), especialmente o falecido, não sem razão chamado de "Damastor" (Rosa, 1994: 406) - cujo nome lembra o monstruoso penedo de Camões - e que é relacionado com déspota, "o grande pior", "ferrabrás e mestre", e cujo "inventário de maldades" "botara na obrigação da ruim fama os mais moços" (Rosa, 1994: 405), para quem era "sordidamente avaro" (Rosa, 1994: 406). Na cena que descreve, "tudo tinha um ar de espantoso" (Rosa, 1994: 405), fazendo prever maiores desgraças, especialmente depois que o Liojorge, "um lagalhé pacífico e honesto", enviara o Damastor Dagobé "para o sem-fim dos mortos". (Rosa, 1994: 405). Para esse narrador, toda a solicitude e gentileza dos irmãos deviam-se apenas ao respeito para com a situação de velório, era um "falso fiar", porque "Aquilo era quando as onças. Mais logo". O "certo solerte contentamento" dos irmãos sobreviventes só podia ser devido à "tenção feita", pois "Saboreavam já o sangrar" (Rosa, 1994: 406), 
enquanto permaneciam juntos, "no miúdo confabulejo", esperando "O assombrável!" (Rosa, 1994: 406). A aceitação do oferecimento do assassino para ajudar a carregar o caixão aumenta o espanto e a percepção de que os Dagobés o olhavam com ódio, enquanto o povo tinha "Fome de perguntidade", e previa: "baixado o caixão à cova, à queima-bucha o matavam; no expirar de um credo" (Rosa, 1994: 408).

Sugerindo que o povo é que se equivocava com sua leitura, diz o narrador, ao supor que o irmão mais mal-encarado teria levado a mão ao cinturão da arma: "Não, a gente é que assim previa, a falsa noção do gesto", para depois relaxar a tensão com o desfecho pacífico e inesperado e a conclusão de que o "saudoso Irmão é que era um diabo de danado..." (Rosa, 1994: 408). Rosa ironiza, assim, o seu leitor, brincando com o clima de tragédia em que o envolve o conto, construído em torno de uma leitura equivocada, passiva e repetidora de significados, que continua a ver fingimento, prepotência e má intenção em sinais sinceros de cordialidade e agradecimento.

Outro tipo de ironia - comumente chamada ironia romântica ou metaliterária - está presente em muitos textos de Guimarães Rosa, como "Pirlimpsiquice", "A estória do homem do Pinguelo", "Recado do morro", "São Marcos" e "Famigerado". Trata-se de ironia que exibe o caráter de fingimento de representação construída ou de brincadeira, de jogo, de arte - da narrativa, e se constrói com artifícios da ironia romântica: espelhamentos, reduplicações e encaixes que se multiplicam e se superpõem, de forma a tornar evidente o caráter artificial de metaliteratura do texto: trata-se de algo que não reproduz a realidade, mas a inventa, como ocorre no citado "Pirlimpsiquice".

Estória simples que se engrandece com o gênio rosiano, "Pirlimpsiquice" aproveita o recurso do teatrinho beneficente que os padres de um colégio usam para reforçar valores ideais nos estudantes, pois só participam da representação os mais aplicados. Os valores mais reforçados acabam sendo, entretanto, os da ironia e do humor, vistos como os únicos capazes de sustentar a representação e salvar a arte, quando tudo parecia perdido, já que coexistem no conto diversos autores, estórias, personagens e receptores e "personagens personificantes”, multiplicando-se máscaras e incongruências. O resultado é um produto fragmentado, que recusa a tradição e exibe a ironia romântica com que se constrói, com seus jogos do ser e do parecer, sua preocupação em afirmar a ilusão das coisas e, antes de tudo, a ilusão da própria arte, que é fingimento, representação que se confessa representação. 
É significativo, nesse sentido, que somente o maluquinho Zé Boné possa salvar a encenação de que se ocupa o conto, quando o drama que seria representado cruza-se com as várias estórias inventadas para preservá-lo. É por não se prender aos significados, ao sentido das histórias, que Zé Boné consegue misturá-las e construir outra estória de sucesso. É por ser ele o "o preenchido beócio" (...), o "que regulava de papalvo" (Rosa, 1994: 415), o "estafermo" (...), o basbaque incapaz de "emendar palavra e meia palavra" (Rosa, 1994: 417), aquele que "Nem na história do drama botava sentido" (Rosa, 1994: 416), o incapaz de guardar segredos (e o que é o segredo senão um sentido estabelecido?) que pode criar algo novo e assim salvar o espetáculo do fracasso, de sua metafórica morte.

Rosa desvela, assim, os bastidores da criação, para desmascarar uma arte que pretende apenas referendar valores. Deixando transparecer na estória do teatrinho de colegiais a sua inquietação quanto à criação estética, o gênio rosiano mostra-a como um exercício lúdico que não deve restringir-se a defender valores ou a imitar, mas deve produzir algo inédito, que enfatize a capacidade de criar, de tecer enunciados, de simular, de fingir, de ludibriar. Se a perspectiva do narrador do conto confirma a concepção hegeliana de arte, cujo objetivo deve ser referendar os valores sociais, o sujeito de sua enunciação pisca o olho ao leitor e semeia no texto as marcas de uma ironia iconoclasta e desconstrutora. Subvertendo a desejada ordem do espetáculo teatral, contrapõe a todo o seu planejamento inicial e à seriedade dos ensaios os imprevistos provocados pela mesma ação educadora. Complica e desconstrói, assim, uma concepção que valoriza o fingimento camuflado e apresenta uma outra proposta de encenação, em que o fingimento é exibido e multiplicado.

Desconstruindo modelos e afirmando como única verdade a representação, a voz enunciadora do conto revela seu objetivo de exibir o nada residual e ser estória - literatura, arte -, exercício crítico que é em primeiro lugar jogo e brincadeira e que propõe, através do lúdico e da criatividade, uma outra cena que recusa a História e seus jogos de poder, para propor uma comunicação mais eficaz entre seres humanos. Mostra assim que a peça - que afinal se encena, depois de muitas peripécias -, subverte todas as histórias previamente preparadas, servidoras do desejo de poder de diferentes grupos sociais. Tem, pois, vida própria, não se comprometendo com nenhum valor, mas construindo-se como arte independente, que, por isso mesmo, denuncia e critica todas as outras versões, servidoras de ideologias ou contra-ideologias. 
Assim, é a partir de vários tipos de ironia que Guimarães Rosa se aproxima do Íon de Platão, revelando a sua percepção de que o homem é um ser de desejos insatisfeitos, o que equivale a reconhecer a sua insatisfação com a realidade. Usando ironias no plano da diegese - e assim complicando a comunicação entre as personagens ou o entendimento entre narradores e leitores intradiegéticos - ou tecendo ironicamente a sua enunciação - especialmente através da ironia bumoresque e da ironia romântica, com a valorização da palavra, o distanciamento de vozes narrativas e a exibição do caráter de tessitura artificiosa e de representação de seu texto -, Guimarães Rosa, esse bruxo da linguagem, ironicamente, indiretamente, comunica-se conosco. E com um toque de ironia romântica lembra-nos que o ser humano deseja o absoluto e tem ânsia de felicidade total, mas está condenado à morte, preso à própria contingência e relatividade. Problemas que o contador de estórias, como o Íon de Platão, pode, entretanto, resolver através de sua mágica e irônica arte de embusteiro porque, embora não possa prometer para sempre a libertação da morte, pode livrar o leitor de seu jugo, por um instante, com suas estórias que se entretecem com ilusão e arte.

Abstract: This study aims at demonstrating that Rosa is a deceiver and a story-teller endowed with divine powers, who, making use of different kinds of irony, induces bis reader into moving away from reality and penetrating the enchanted meandering world of fiction.

Key words: Guimarães Rosa, irony, disguising, metaliterature.

\section{Referências Bibliográficas}

Almansi, G. L'affaire mystérieuse de l'abominable tongue-in-cheek. Poétique, Paris, n. 36, p. 413-426, nov. 1978.

Duarte, Lélia Parreira. Ironia, humor e fingimento literário. Cadernos de pesquisa do NAPq, Belo Horizonte, FALE/UFMG, n. 15, p. 5478, 1994.

Ferraz, Maria de Lourdes. A ironia romântica. Lisboa: Imprensa Nacional - Casa da Moeda, 1987.

Jankélévith, Vladimir. L'ironie. Paris: Flammarin, 1964.

Rosa, João Guimarães. Aletria e hermenêutica. In: Ficção completa. Rio de Janeiro: Nova Aguilar, 1994. Tutaméia, p. 519-526. 